\title{
PENGARUH PENERAPAN METODE PEMBELAJARAN PRAKTIKUM TERHADAP KETERAMPILAN BERPIKIR KRITIS MATEMATIKA SISWA KELAS VIII SMP N 3 SUMBER KABUPATEN CIREBON
}

\author{
Lilis Kurniawati, Reza Oktiana Akbar, Muhamad Ali \\ Misri
}

Tadris Matematika, IAIN Syekh Nurjati Cirebon
Jl. Perjuangan By Pass Sunyaragi Cirebon

\begin{abstract}
Critical thinking can be surely taught and practiced for all educational graders. However, in educational field, it is still few teachers who facilitate students' mathematics critical thinking. The aims of this study is to know whether the implementation of practical learning method significantly affects students' mathematics critical thinking skills in learning mathematic at junior high school. The significances of the study are to give students' active role in learning process, to improve students' comprehension towards mathematic concept, and to upgrade students' mathematics critical thinking.

This research method is experiment method with design path analysis. The population was taken from all eighth graders which are 265 students of SMP N 3 Sumber period 2014/2015. The, the random sampling was used to gain 44 students of VIII E grade. The technique of data collection including questionnaire and essay test was used.

The results of questionnaire showed that 25 or $57 \%$ students gave responses very positively toward the implementation of practical learning method. Then, 19 or $43 \%$ students gave positive response toward the implementation of practical learning method. The result of t-test showed that there is a linier relationship between practical learning method and mathematics critical thinking with $\hat{Y}=1,341$ X. Coefficient with positive response means that there is a significant relationship between practical learning method and mathematics critical thinking by implementing practical learning methods very often may improve students' mathematics critical thinking. According to the result of t-test, it is showed that $t_{\text {account }}=6,509>t_{\text {tabel }}=2,020$. It can be concluded that the implementation of practical learning method significantly affect students' mathematics critical thinking at VIII E grade of SMP Negeri 3 Sumber Kabupaten Cirebon.
\end{abstract}

Keywords : Practical Learning Methods, Critical Thinking Skills. 


\section{PENDAHULUAN}

Menurut data hasil studi TIMMS dan PISA yang menunjukan bahwa kemampuan siswa SMP Indonesia khususnya dalam bidang matematika masih dibawah standar dunia internasional. Hasil terbaru TIMMS 2011 menempatkan Indonesia di peringkat ke-38 dari 42 negara dan hasil terbaru PISA 2012 lebih memprihatinkan lagi, Indonesia berada di peringkat ke-64 dari 65 negara (Mahmuzah dan Ikhsan, 2014: 44).

Hal ini serupa dengan temuan Elder dan Paul dalam Suwarma (2009: 4) merupakan direktur Foundation For Critical Thinking mengenai sedikitnya siswa Sekolah Dasar yang diajarkan bagaimana menganalisis. Secara alamiah, kehidupan seseorang selalu mengalami perubahan sehingga Ia perlu bekal untuk dapat beradaptasi dalam situasi baru. Bekal ini berupa kemampuan dasar untuk menganalisis sudut pandang berbeda, merekognisi tidak konsistenan, menganalisis pilihan informasi yang beragam dan menyusun pilihan informatif berdasarkan informasi yang akurat, dengan memfasilitasi seseorang untuk terbiasa berpikir kritis dapat mengurangi pemikiran yang bias, berubah-ubah, parsial, tidak informatif, atau yang merupakan prasangka.

Kualitas sumber daya manusia tidak terlepas dari kualitas pendidikan, dimana salah satu komponen utamanya adalah guru. Gurulah yang berada di garda terdepan dalam menciptakan sumber daya manusia. Guru berhadapan langsung dengan peserta didik dikelas melalui proses pembelajaran, ditangan gurulah akan dihasilkan peserta didik yang berkualitas, baik secara akademis, skill (keahlian), kematangan emosional, dan moral serta spiritual (Sukmandari, 2012: 314).
Realitas pendidikan dewasa ini masih hanya sebatas transfer of knowladge, belum sampai transfer of value, yang menciptakan konsep pendidikan kritis, bahwa pendidikan adalah suatu proses dimana suatu bangsa mempersiapkan generasi mudanya untuk menjalankan kehidupan dan untuk memenuhi tujuan hidup secara efektif dan efisien (latihan fisik, mental dan moral). Pada hakikatnya pendidikan adalah proses humanisasi (memanusiakan manusia) yang mengandung implikasi bahwa tanpa pendidikan, manusia tidak akan menjadi manusia dalam arti yang sebenarnya.

Solusi yang dalam hal ini adalah dengan pendidikan humanistik. Ki Hajar Dewantara merupakan salah satu pendidik asli Indonesia yang juga mengusung konsep tersebut. Menurutnya manusia memiliki daya jiwa yaitu cipta, rasa, dan karsa. Pengembangan manusia seutuhnya menuntut pengembangan semua daya secara seimbang.

Kontribusi pendidikan humanistik Ki Hajar Dewantara terhadap pendidikan nasional Indonesia antara lain adalah sebagai peletak dasar pendidikan nasional, pencetus konsep pendidikan demokrasi dalam pendidikan yang semuanya terformulasikan dalam slogan pendidikan nasional Tut Wuri Handayani (Wangid, 2009: 130).

Menurut James dalam Winataputra (2001: 16) matematika adalah konsep ilmu tentang logika mengenai bentuk, susunan, besaran dan konsep-konsep yang berhubungan satu dengan yang lainnya dengan jumlah yang banyak yang terjadi ke dalam tiga bidang yaitu : aljabar, analisis, dan geometri. Untuk mencapai tujuan kegiatan belajar mengajar (KBM) yang efektif dan efisien, salah 
satu komponen penentu dalam kegiatan ini adalah guru.

Berdasarkan data hasil wawancara yang telah dilakukan kepada salah satu guru mata pelajaran matematika di SMP Negeri 3 Sumber, permasalahan yang terjadi selama ini adalah karena siswa kurang dapat menganalisis informasi yang ada dan cenderung menerima apa adanya informasi yang disampaikan maupun yang tertulis dalam buku, siswa cenderung pasif dalam proses pembelajaran dan malu bertanya sehingga butuh waktu lama agar siswa dapat memahami dan mengerti apa yang guru sampaikan. Upaya memfasilitasi agar kemampuan berpikir kritis siswa berkembang menjadi sangat penting, mengingat beberapa hasil penelitian masih mengindikasikan rendahnya kemampuan berpikir kritis siswa Indonesia (Fachrurazi, 2011: 77).

Pada proses pembelajaran, tidak banyak guru yang berupaya menciptakan lingkungan belajar yang kondusif untuk meningkatkan kemampuan berpikir kritis matematika, hal ini nampak ketika guru menjelaskan materi yang telah disiapkan, guru memberikan soal latihan yang bersifat rutin dan prosedural, siswa hanya mencatat atau menyalin materi dan siswa cenderung menghafal rumus-rumus atau aturan-aturan matematika secara tidak bermakna dan pengertian. Kondisi ini mencerminkan suatu proses pembelajaran matematika yang tidak berpusat pada siswa dan tidak memfasilitasi kemampuan berpikir matematika.

Salah satu metode yang bisa diterapkan oleh seorang guru adalah metode pembelajaran praktikum, metode pembelajaran praktikum merupakan proses pemecahan masalah melalui kegiatan manipulasi variabel dan pengamatan variabel. Praktikum merupakan salah satu pengajaran yang berpusat pada peserta didik yang mengambarkan strategi- strategi pengajaran dimana guru lebih memfasilitasi dari pada mengajar langsung, dalam strategi pengajaran yang berpusat pada peserta didik, guru secara sadar menempatkan perhatian yang lebih banyak pada keterlibatan, inisiatif, dan interaksi sosial peserta didik (Hidayati, 2012: 4).

Melalui praktikum peserta didik juga dapat mempelajari sains dan pengamatan langsung terhadap gejala-gejala maupun proses-proses sains, dapat melatih keterampilan berpikir ilmiah, dapat menanamkan dan mengembangkan sikap ilmiah, dapat menemukan dan memecahkan berbagai masalah baru melalui metode ilmiah dan lain sebagainya, kemampuan ini bisa dikembangkan melalui kegiatan praktikum.

\section{ACUAN TEORITIK}

Kerangka Teori

Pengertian Belajar dan Pembelajaran

Menurut pendapat tradisional belajar adalah menambah dan mengumpulkan sejumlah pengetahuan, disini yang dipentingkan pendidikan intelektual kepada anak-anak diberikan berbagai macam pelajaran untuk menambah pengetahuan yang dimilikinya, terutama dengan jalan menghafal (Aqib, 2010: 41). Menurut Anisah (2011: 12), belajar adalah suatu kegiatan seseorang yang bisa dilakukan secara sengaja atau secara acak. Belajar bisa melibatkan pemerolehan informasi atau keterampilan, sikap baru, penegertian, atau nilai. Belajar biasanya disertai perubahan tingkah laku dan berlangsung sepanjang hayat. Belajar sering diartikan sebagai proses atau hasil. Berdasarkan pemikiran tersebut, pendidikan adalah usaha sistematis yang terorganisasi untuk memajukan belajar, membina kondisi, dan menyediakan 
kegiatan yang mengakibatkan terjadinya peristiwa belajar.

Menurut Slameto (1995: 2) belajar adalah suatu proses usaha yang dilakukan seseorang untuk memperoleh suatu perubahan tingkah laku yang baru secara keseluruhan, sebagai hasil pengalamannya sendiri dalam berinteraksi dengan lingkungannya. Berdasarkan definisi di atas, dapat diambil kesimpulan bahwa belajar adalah proses perubahan di dalam diri manusia, baik itu sifat, tingkah laku atau pun pengetahuan. Sedangkan proses belajar mengajar adalah interaksi yang dilakukan siswa dan guru ketika proses belajar mengajar sedang berlangsung.

Metode Pembelajaran

Menurut Sumiyati (2008: 91), Metode pembelajaran yang ditetapkan guru memungkinkan siswa belajar proses (learning by process), bukan hanya belajar produk (learning by product). Belajar produk pada umumnya hanya menekankan pada segi kognitif, sedangkan belajar proses dapat memungkinkan tercapainya tujuan belajar dari segi kognitif, afektif (sikap) maupun psikomotor (keterampilan).

Oleh karena itu, pembelajaran harus diarahkan untuk mencapai sasaran tersebut, yaitu lebih banyak menekankan pembelajaran melalui proses. Proses pembelajaran menuntut guru dalam merancang berbagai metode pembelajaran yang memungkinkan terjadinya proses pembelajaran pada diri siswa. Rancangan ini merupakan acuan dan panduan, baik bagi guru itu sendiri maupun bagi siswa.

Efektivitas Penggunaan Metode Pembelajaran

Metode pembelajaran yang digunakan pada dasarnya hanya berfungsi sebagai bimbingan agar siswa belajar. Metode pembelajaran ini ditujukan untuk bimbingan belajar dan memungkinkan setiap individu siswa dapat belajar sesuai dengan bakat dan kemampuan masingmasing.
Metode pembelajaran dikatakan efektif jika peserta didik dapat terlibat aktif dalam proses pembelajaran, metode pembelajaran harus disesuaikan dengan materi dan kemampuan peserta didik serta fasilitas yang ada disekolah tersebut.

Macam-macam

Metode

Pembelajaran

Menurut hamdani (2010: 82), terdapat macam-macam metode pembelajaran diantaranya adalah : a) Ceramah; b) Tanya jawab; c) Diskusi kelompok; d) Praktikum; e) Demonstrasi dan eksperimen; f) Tugas belajar dan resitasi; g) Kerja kelompok; h) Sosiodrama (role playing); $h$ ) Pemecahan masalah (problem solving); i) Sistem regu; j) Karyawisata (field-trip); k) Manusia sumber (resource person); l) Survei masyarakat; m) Simulasi; n) Studi kasus; o) Tutorial; p) Curah gagasan; q) Studi bebas; r) Kelompok tanpa pemimpin; s) Latihan (drill); t) Latihan kepekaan;

Berdasarkan uraian macam-macam metode pembelajaran diatas, peneliti memilih metode praktikum karena dengan metode ini siswa dapat berperan aktif dalam proses pembelajaran sehingga dapat merangsang keterampilan berpikir kritis matematika siswa

\section{Metode Praktikum}

Praktikum berasal dari kata "praktik", praktik adalah kegiatan belajar yang menuntut siswa berlatih menerapkan teori, konsep, prosedur, dan keterampilan dalam situasi nyata atau buatan secara terprogram/terstruktur di bawah pengawasan atau bimbingan langsung dari pembimbing/supervisor atau secara mandiri.

Menurut Djamarah dalam Hidayati (2012: 4), metode pembelajaran praktikum adalah Cara penyajian pelajaran dimana peserta didik melakukan percobaan dengan mengalami dan membuktikan sendiri sesuatu yang dipelajari. 
Dalam proses belajar mengajar dengan metode percobaan ini peserta didik diberi kesempatan untuk mengalami sendiri atau melakukan sendiri, mengikuti suatu proses, mengamati suatu objek, menganalisis, membuktikan dan menarik kesimpulan sendiri mengenai suatu objek, keadaan atau proses sesuatu.

Pada pembelajaran berbasis praktikum siswa lebih diarahkan pada eksperimental learning (belajar berdasarkan pengalaman konkret), diskusi dengan teman, yang selanjutnya akan diperoleh ide dan konsep baru (Hayat dan Anggraeni, 2011: 143). Metode praktikum merupakan metode pembelajaran dengan proses pemecahan masalah melalui kegiatan manipulasi variabel-variabel dan pengamatan variabel.

Faktor-faktor yang Mempengaruhi Pembelajaran Praktikum

Menurut Lazarowitz dan Tamir dalam Hidayati (2012: 10-12), ada lima faktor yang dapat memfasilitasi keberhasilan pembelajaran praktikum yaitu: kurikulum, sumber daya, lingkungan belajar, keefektifan mengajar, dan strategi assesmen.

Tahap-tahap Metode Praktikum

Pada pelaksanaan praktikum agar hasil yang diharapkan dapat dicapai dengan baik maka perlu dilakukan langkah-langkah sebagai berikut:

Langkah Persiapan

Persiapan untuk metode praktikum antara lain: Menetapkan tujuan praktikum, mempersiapkan alat dan bahan yang diperlukan, mempersiapkan tempat praktikum, mempertimbangkan jumlah peserta didik dengan jumlah alat yang tersedia dan kapasitas tempat praktikum, mempersiapkan faktor keamanan dari praktikum yang akan dilakukan, mempersiapkan tata tertib dan disiplin selama praktikum, membuat petunjuk praktikum dan juga langkahlangkah praktikum.

Langkah pelaksanaan

Selama berlangsungnya proses pelaksanaan metode praktikum, guru perlu melakukan observasi terhadap proses praktikum yang sedang dilaksanakan baik secara menyeluruh maupun perkelompok. Tindak Lanjut Metode Praktikum Setelah melaksanakan praktikum, kegiatan selanjutnya adalah : meminta peserta didik membuat laporan praktikum, mendiskusikan masalah-masalah yang terjadi selama praktikum, memeriksa kebersihan alat dan menyimpan kembali semua perlengkapan yang telah digunakan

Kelebihan dan Kekurangan Metode Praktikum

Metode praktikum mempunyai kelebihan dan kekurangan sebagai berikut (Djamarah, 2006: 84-85):

Kelebihan Metode Praktikum

Membuat peserta didik lebih percaya atas kebenaran atau kesimpulan berdasarkan percobaan dan dapat membina peserta didik untuk membuat trobosan-trobosan baru dengan penemuan dari hasil percobaannya dan bermanfaat bagi kehidupan manusia. Hasil-hasil percobaan yang berharga dapat dimanfaatkan untuk kemakmuran umat manusia.

Kekurangan Metode Praktikum Metode ini lebih sesuai dengan bidang-bidang sains dan teknologi, metode ini memerlukan berbagai fasilitas peralatan dan bahan yang tidak selalu mudah diperoleh dan 
mahal, metode ini menuntut ketelitian, keuletan ketabahan setiap percobaan tidak selalu memberikan hasil yang sesuai karena mungkin ada faktor tertentu yang berada diluar jangkauan kemampuan.

Berdasarkan uraian di atas, dapat disimpulkan bahwa metode praktikum merupakan suatu cara dimana peserta didik melakukan percobaan dengan mengalami untuk membuktikan sendiri suatu pertanyaan yang dipelajari sehingga dapat mengembangkan sikap ilmiah dalam diri peserta didik, juga memberikan gambaran dan pengertian yang lebih jelas dari pada hanya penjelasan lisan sehingga sangat bermanfaat bagi keperluan hidup sehari-hari.

Hasil Belajar Matematika

Pengertian Hasil Belajar

Hasil belajar yang sering disebut dengan istilah "scholastic achievement" atau "academic achievement" adalah seluruh kecakapan dan hasil yang dicapai melalui proses belajar mengajar di sekolah yang dinyatakan dengan angka-angka atau nilai-nilai berdasarkan tes hasil belajar (Purwanto, 2011: 3). Menurut Mulyasa dalam Mappeasse (2010: 4), hasil belajar merupakan prestasi belajar peserta didik secara keseluruhan, yang menjadi indikator kompetensi dasar dan derajat perubahan perilaku yang bersangkutan.

Berdasarkan penjelasan di atas disimpulkan bahwa hasil belajar matematika adalah kemampuankemampuan yang dimiliki siswa dengan ditandai perubahan perilaku setelah menerima pembelajaran matematika, baik dalam aspek kognitif yang bisa berfikir logis dan kritis, dalam aspek afektif yang menjadi lebih teliti dan hati-hati dalam bertindak, maupun aspek psikomotorik yang menjadi lebih terampil dan kreatif dalam mengerjakan sesuatu. Perubahan tingkah laku sebagai hasil dari belajar adalah perubahan perilaku secara keseluruhan, bukan hanya salah satu aspek saja. Pembelajaran belum dikatakan lengkap apabila hanya menghasilkan perubahan-perubahan dari satu atau dua aspek saja.

Keterampilan Berpikir Kritis Matematika

Lilisari yang dikutip oleh Hasanudin mengemukakan bahwa berpikir secara umum dianggap sebagai proses kognitif, tindakan mental untuk memperoleh pengetahuan.

Berpikir kritis merupakan suatu proses untuk mengolah atau menganalisis seluruh ide atau informasi yang berkaitan dengan masalah yang akan dipecahkan, secara cermat, sehingga dapat menemukan langkah-langkah yang tepat untuk memecahkan permasalahan tersebut (Wulandari, 2013: 3).

Merujuk pada beberapa pemaparan diatas maka dapat disimpulkan bahwa keterampilan berpikir kritis harus dikembangkan sejak dini. untuk itu, perlu strategi atau metode khusus yang dapat menunjang siswa agar dapat berpikir kritis.

Dalam kurikulum berpikir kritis, menurut Ennis dalam Suwarma (2009: 11) mengemukakan terdapat dua belas indikator berpikir kritis yang dikelompokan dalam lima kemampuan berpikir, yaitu (1) memberikan penjelasan sederhana (elementary clarification), (2) membangun keterampilan dasar (bassic support), (3) menyimpulkan (inference), (4) membuat penjelasan lebih lanjut (advance clarification) 
dan (5) mengatur strategi dan taktik (strategies and tactics).

Keterkaitan Antar Variabel

Metode praktikum (Variabel X) adalah cara penyajian pelajaran dimana peserta didik melakukan percobaan dengan mengalami dan membuktikan sendiri sesuatu yang dipelajari, mengikuti suatu proses, mengamati suatu objek, menganalisis, membuktikan dan menarik kesimpulan sendiri mengenai suatu objek, keadaan atau proses sesuatu. Hal ini termasuk kedalam indikator keterampilan berpikir kritis matematika (Variabel Y) sehingga metode praktikum dengan keterampilan berpikir kritis matematika ada keterkaitan

Bangun Ruang Sisi Datar

Pelajaran matematika secara garis besar terdiri dari 4 cabang yaitu aritmatika, aljabar, geometri dan analisis dalam Rohati (2011: 63). Dari keempat cabang tersebut geometri memegang peranan yang cukup penting dalam proses pembelajaran matematika. Geometri adalah salah satu cabang Matematika yang mempelajari tentang titik, garis, bidang dan benda-benda ruang, diantaranya yaitu: kubus dan balok.

\section{METODOLOGI PENELITIAN}

Metode dan Desain Penelitian

Metode Penelitian ini adalah metode eksperimen. Menurut Arikunto dalam Susanti (2011: 55) metode eksperimen merupakan penelitian untuk mengetahui ada tidaknya akibat dari suatu yang dikenakan pada subjek selidik.

Desain penelitian ini menggunakan desain analisis jalur (path analysis). Menurut Ridwan dalam Haniah (2013: 58) model path analysis digunakan untuk menganalisis pola hubungan antar variabel dengan tujuan untuk mengetahui pengaruh langsung maupun tidak langsung seperangkat variabel bebas (eksogen) terhadap variabel terikat (endogen).

Populasi dan Sampel

Populasi dalam penelitian ini adalah seluruh siswa kelas VIII di SMP Negeri 3 Sumber pada semester genap tahun ajaran 2014/2015, data diperoleh dari petugas Tata Usaha (TU) di SMP Negeri 3 Sumber.

Pengambilan sampel dalam penelitian ini menggunakan teknik Sample Random Sampling. Sampel dalam penelitian ini dipilih dengan cara pengundian sehingga terpilih kelas VIII E sebagai sampel dengan jumlah 44 siswa, untuk mengetahui data siswa selengkapnya dapat dilihat pada lampiran B.

Teknik Pengumpulan Data

Instrumen Pengumpulan Data Instrumen Angket

Instrument yang digunakan untuk mengukur variabel $\mathrm{X}$ (metode pembelajaran praktikum) dalam penelitian ini adalah angket, dalam penyusunan angket terdiri dari 20 item pernyataan dan masing-masing pernyataan memiliki 4 alternative jawaban yaitu setuju, sangat setuju, tidak setuju dan sangat tidak setuju. Angket dalam penelitian ini dalam bentuk skala likert antara $1-4$ (Riduwan, 2003: 13).

Instrumen Tes

Tes merupakan salah satu alat untuk melakukan pengukuran, yaitu alat untuk mengumpulkan informasi karakteristik suatu objek dalam Rofiah (2013: 17). Tes diberikan berbentuk tes uraian sebanyak 8 soal, sebelum instrumen tes keterampilan berpikir kritis siswa 
digunakan dalam penelitian ini, maka instrumen tersebut diuji cobakan terlebih dahulu dengan tujuan untuk mengetahui gambaran tentang terpenuhi atau tidaknya syarat-syarat sebagai instrument pengambilan data. Setelah data didapatkan, kemudian melakukan penilaian soal instrument tes (Purwanto, 2000: 112) tersebut dengan cara :

$$
S=\frac{R}{N} x 100 \%
$$

Keterangan :

$S=$ Skor

$R=$ Total jawaban siswa

$N=$ Banyak responden

Teknik Analisis Data

Uji Prasyarat Analisis

Uji Normalitas

$$
\mathbf{D}_{n}=\boldsymbol{S U} \boldsymbol{P}_{\boldsymbol{x}} \text { 定 } \boldsymbol{F}_{\boldsymbol{n}} \mathbf{X}-\boldsymbol{F}(\boldsymbol{X}) \text { ? }
$$

Keterangan:

$\mathrm{D}=$ Deviasi Maksimum.

$\mathrm{F}_{\mathrm{n}}(\mathrm{X})=$ Frekuansi kumulatif distribusi data.

$\mathrm{F}(\mathrm{X})=$ Kumulatif distribusi normal.

Dimana,

$$
\begin{aligned}
F_{n} X=\frac{1}{n}{ }_{i=1}^{n} I_{x i \leq x} & \operatorname{dan} F x \\
& ={ }_{-\infty}^{\mathrm{z}} \frac{1}{\text { ó } \sqrt{2 \pi}} e^{-\frac{t^{2}}{2 \sigma^{2}} d t}
\end{aligned}
$$

Uji Homogenitas

Untuk memudahkan perhitungan uji homogenitas peneliti menggunakan rumus Levene Statistic (Fahmy, 2013: 38) sebagai berikut :

$$
L=\frac{W-k^{\prime} \sum_{i=1}^{k \prime} W_{i}\left(\bar{Z}_{i}-\bar{Z}\right)^{2}}{k^{\prime}-1 \sum_{i=1}^{k \prime} \sum_{l=1}^{N i} W_{i l} Z_{i l}-\bar{Z}_{i}{ }^{2}}
$$

Keterangan :

$\mathrm{L} \quad=$ Hasil pengujian

$\mathrm{K}=$ Jumlah kelompok yang berbeda

$\mathrm{W} \quad=$ Jumlah sampel

$\mathrm{W}_{i}=$ Jumlah sampel dalam kelompok ke- $i$
$\mathrm{W}_{i l}=$ Nilai sampel ke- $l$ dari kelompok ke- $i$

Jika nilai sig $<0,05$ artinya data heterogen Jika nilai sig $>0,05$ artinya data homogen Uji Linearitas Regresi

Analisis regresi digunakan untuk mengetahui besarnya pengaruh satu variabel bebas atau lebih terhadap satu variabel tidak bebas (Sugiarti, 2001: 1). Uji ini bertujuan untuk mengetahui apakah variabel $\mathrm{X}$ dan variabel Y memiliki hubungan linear atau tidak secara signifikan. Uji ini digunakan sebagai prasyarat dalam analisis korelasi atau regresi linear. Jika nilai sig $<0,05$ artinya data linear, Jika nilai sig $>0,05$ artinya data non linear.

Uji Hipotesis

Uji Koefisien Regresi

Untuk menghitung koefisien regresi sederhana rumus yang digunakan untuk mencari a dan b (Abdurahman, 2011:213) adalah :

$$
\begin{gathered}
a=\frac{\sum r-b \sum x}{N}=\widehat{Y}-b \widehat{X} \\
b=\frac{n \sum X Y-\sum X \sum Y}{n \sum X^{2}-\sum X^{2}}
\end{gathered}
$$

Keterangan:

$\hat{X}=$ Rata-rata skor variabel $\mathrm{X}$

$\hat{Y}=$ Rata-rata skor variabel Y

Uji Regresi Linear Sederhana

Dimana:

$$
\widehat{\boldsymbol{Y}}=\boldsymbol{a}+\boldsymbol{b} \boldsymbol{X}
$$

$\hat{Y} \quad=$ Variabel terikat.

$\mathrm{X} \quad=$ Variabel bebas.

a $\quad=$ Nilai konstanta.

$\mathrm{b}=$ Koefisien regresi variabel bebas.

Dalam hal ini b sebagai arah regresi yang menunjukan nilai peningkatan $(+)$ atau penurunan (-) variabel dependen $(\mathrm{Y})$.

Uji Kebaikan Model

$\mathrm{KD}=\mathrm{r}^{2} \mathrm{x} 100 \%$

Keterangan :

$\mathrm{KD}=$ besarnya koefisien penentu (determinasi)

$\mathrm{r} \quad=$ koefisien korelasi

Uji Hipotesis dengan t-test 
$\boldsymbol{t}_{\boldsymbol{h}}=\frac{b_{1}}{S b_{1}}$

Keterangan:

$t_{\mathrm{h}} \quad=$ nilai $\mathrm{t}$ hitung

$b_{1} \quad=$ koefisien regresi

$\mathrm{Sb}_{1}=$ standar error regesi

Bandingkan nilai t-hitung dengan nilai t-tabel, dengan ketentuan sebagai berikut :

Jika nilai t-Hitung $>$ t tabel maka $H_{0}$ ditolak dan $H_{a}$ (ada pengaruh yang signifikan).

Jika nilai t-Hitung $<\mathrm{t}$ tabel maka $H_{0}$ diterima dan $H_{a}$ (tidak ada pengaruh yang signifikan).

Hipotesis Statistik

$\mathrm{H}_{\mathrm{o}}: \beta_{1}=0$

$\mathrm{H}_{\mathrm{a}}: \beta_{1} 1 \neq 0$

Tolak $\mathrm{H}_{0}$ jika thitung $>\mathrm{t}_{\text {tabel }}$ kreiteria penolakan atau penerimaan hipotesis untuk taraf signifikasi 0,05 atau á $=5 \%$ atau taraf keyakinan $95 \%$ atau 0,95 .

Jika thitung $\geq t_{\text {tabel}}, \mathrm{H}_{\mathrm{o}}$ ditolak dan $\mathrm{Ha}$ diterima.

Jika thitung $\leq \mathrm{t}_{\text {tabel }}, \mathrm{H}_{\mathrm{o}}$ diterima dan $\mathrm{Ha}$ ditolak.

\section{HASIL DAN PEMBAHASAN}

Deskripsi Data

Deskripsi Variabel X ( Metode Pembelajaran Praktikum

Deskripsi data angket $N$ adalah jumlah responden yang mengisi angket yaitu 44 responden, minimum adalah nilai terendah yaitu 70 , maximum adalah nilai terbesar yaitu 88, sum adalah jumlah skor keseluruhan yaitu 3550 , mean adalah nilai rata-rata yaitu 80,68, standar deviation adalah ukuran penyebaran data dari ratarata nilainya yaitu 4,46 dan variance adalah varian data yang didapat dari kelipatan standar deviasinya yaitu 19,896 .
Adapun persentase angket respon sisa dengan diterapkannya metode pembelajaran praktikum terdapat 25 siswa yang memberikan respon sangat positif dengan persentase sebesar 57\% dan 19 siswa yang memberikan respon positif dengan persentase sebesar 43\%. Hal ini menunjukan bahwa sebagian siswa merespon baik terhadap pembelajaran dengan menggunakan metode praktikum.

Persentase respon siswa adalah 85\% hal ini menunjukan bahwa metode pembelajaran praktikum mempengaruhi keterampilan berpikir kritis siswa. Sehingga dapat disimpulkan bahwa metode pembelajaran praktikum cocok diterapkan pada pokok bahasan bangun ruang sisi datar.

Pembahasan

Berdasarkan deskripsi data angket diperoleh $N$ adalah jumlah responden yang mengisi angket yaitu 44 responden, minimum adalah nilai terendah yaitu 70 , maximum adalah nilai terbesar yaitu 88, sum adalah jumlah skor keseluruhan yaitu 3550, mean adalah nilai rata-rata yaitu 80,68 , standar deviation adalah ukuran penyebaran data dari rata-rata nilainya yaitu 4,46 dan variance adalah varian data yang didapat dari kelipatan standar deviasinya yaitu 19,896 .

Berdasarkan hasil persentase dari penyebaran angket bahwa penerapan metode pembelajaran praktikum yang telah diberikan peneliti kepada 44 responden bahwa 25 siswa yang memberikan respon sangat positif dengan persentase sebesar 57\% dan 19 siswa yang memberikan respon positif dengan persentase sebesar 43\%. Hal ini 
menunjukan bahwa sebagian siswa merespon baik terhadap penerapan pembelajaran dengan menggunakan metode pembelajaran praktikum.

Persentase tertinggi dari angket respon siswa adalah indikator 7 sebesar $88 \%$ yaitu mampu menyelesaikan soal dan persentase paling rendah adalah indikator 3 sebesar $66 \%$ yaitu melibatkan siswa secara aktif dalam proses pembelajaran.

Berdasarkan deskripsi data diperoleh bahwa $N$ adalah banyaknya responden yang mengisi instrumen test yaitu 44 orang, minimum adalah nilai terendah yaitu 70, maximum adalah nilai tertinggi yaitu 100, sum adalah jumlah skor keseluruhan hasil belajar siswa setelah diberikan treatment dengan menggunakan metode pembelajaran praktikum yaitu 3700 , mean atau nilai rata-rata sebesar 84, standar deviation adalah ukuran penyebaran data dari ratarata nilainya yaitu 8,44 dan variance adalah varian data yang didapat dari kelipatan standar deviasinya yaitu 71,247.

Berdasarkan hasil persentase tes terdapat 14 siswa mendapat skor sangat baik dengan persentase $31,82 \%, 20$ siswa mendapat skor baik dengan persentase $45,46 \%$ dan 10 siswa mendapat skor sedang dengan persentase 22,73\%. Hal ini menunjukan bahwa sebagian besar siswa mampu menjawab soal instrumen test keterampilan berpikir kritis.

Persentase tertinggi dari hasil test siswa adalah item soal 1 sebesar 94\% dengan indikator memberikan penjelasan sederhana dan mengatur strategi dan taktik, sedangkan persentase terendah adalah item soal 2 sebesar $75 \%$ dengan indikator membangun keterampilan dasar, mengatur strategi dan taktik dan menyimpulkan.

Berdasarkan hasil pengujian normalitas dengan uji KolmogorovSmirnov dengan kriteria pengujian $\mathrm{H}_{0}$ diterima jika nilai signifikansi > 0,05 dan $\mathrm{H}_{0}$ ditolak jika nilai signifikansi < 0,05. Hasil yang didapat adalah nilai sig. 0,061. Nilai signifikansi pada tabel diatas lebih besar dari 0,05 maka variabel metode pembelajaran praktikum dan variabel berpikir kritis berdistribusi normal.

Berdasarkan output uji normalitas dengan Normal Q-Q Plot didasarkan pada garis yang melintang dari pojok kiri bawah ke kanan atas, sehingga membentuk arah diagonal dapat disebut sebagai garis acuan normalitas. Berdasarkan grafik di atas, titik-titik tersebar mendekati garis lurus, dengan demikian berdasarkan hasil pengujian normalitas dengan Q-Q Plot terbukti bahwa data metode pembelajaran praktikum dan berpikir kritis siswa berdistribusi normal.

Berdasarkan hasil pengujian homogenitas dengan uji levene statistics dengan kriteria pengujianH $_{0}$ diterima jika nilai signifikansi $>0,05$ dan $\mathrm{H}_{0}$ ditolak jika nilai signifikansi $<0,05$. Hasil yang didapat adalah taraf signifikansi sebesar 0,317. Hal ini menunjukan bahwa angket metode pembelajaran praktikum dan tes keterampilan berpikir kritis siswa berdistribusi homogen karena nilai signifikansi lebih besar dari 0,05. Hal ini menunjukan bahwa kedua nilai memiliki variansi yang sama.

Berdasarkan analisis data yang dilakukan, bahwa terdapat 
hubungan linear antara metode pembelajaran praktikum dengan keterampilan berpikir kritis siswa, kriteria kelinearan regresi yaitu Jika nilai sig $<0,05$ artinya data linear, Jika nilai sig $>0,05$ artinya data non linear.

Uji hipotesis dilakukan dengan menggunakan uji statistik yaitu uji t dengan ketentuan hipotesis sebagai berikut :

$\mathrm{H}_{0} \quad$ : Tidak terdapat pengaruh metode pembelajaran praktikum terhadap keterampilan berpikir kritis siswa.

$\mathrm{H}_{\mathrm{a}} \quad$ : terdapat pengaruh metode pembelajaran praktikum terhadap keterampilan berpikir kritis siswa.

Berdasarkan hasil output SPSS diperoleh nilai sig. 000, hasil regresi yang diperoleh 1,341 sehingga thitung $>$ tabel yaitu $6,509>2,020$ maka $\mathrm{H}_{0}$ ditolak artinya terdapat pengaruh secara signifikan antara pembelajaran menggunakan metode praktikum terhadap keterampilan berpikir kritis siswa dari rumus persamaan awal yaitu $\hat{Y}=\mathrm{a}+\mathrm{b} \mathrm{X}$, dengan demikian persamaan untuk kedua variabel adalah: $\hat{Y}=1,341 \mathrm{X}$.

Dilihat dari uji kebaikan model koefisien determinasi ( $R$ Square) sebesar $0,502 \%$ variabel berpikir kritis dijelaskan oleh variabel penggunaan metode pembelajaran praktikum dan sisanya sebesar 0,498\% dijelaskan oleh variabel lain diluar dari penelitian. Faktor-faktor lain menurut Djamarah (2008:176) yang turut mempengaruhi hasil belajar siswa antara lain seperti faktor lingkungan, faktor instrumental, faktor fisiologis dan faktor psikologis. Berdasarkan pemaparan diatas dapat disimpulkan bahwa metode pembelajaran praktikum cocok diterapkan di Kelas VIII E SMP Negeri 3 Sumber.

PENUTUP

Kesimpulan
Berdasarkan penelitian yang telah dilakukan dikelas VIII E SMP Negeri 3 Sumber Kabupaten Cirebon tahun pelajaran 2014/2015 menggunakan instrumen penelitian berupa angket dengan bentuk skala likert untuk mengetahui respon siswa terhadap penerapan metode pembelajaran praktikum dan instrumen test soal uraian untuk mengetahui kemampuan berpikir kritis siswa. Peneliti dapat menyimpulkan sebagai berikut :

Metode pembelajaran praktikum terlihat dari hasil angket respon siswa dengan diterapkannya metode pembelajaran praktikum terdapat 25 siswa yang memberikan respon sangat positif dengan persentase sebesar 57\% dan 19 siswa yang memberikan respon positif dengan persentase sebesar 43\%. Hal ini menunjukan bahwa sebagian siswa merespon baik terhadap penerapan pembelajaran dengan metode praktikum.

Hasil dari test keterampilan berpikir kritis siswa setelah diberikan treatment dengan menggunakan metode pembelajaran praktikum. Hasilnya terdapat 14 siswa mendapat skor sangat baik dengan persentase $31,82 \%, \quad 20$ siswa mendapat skor baik dengan persentase $45,46 \%$ dan 10 siswa mendapat skor sedang dengan persentase 22,73\%. Hal ini menunjukan bahwa sebagian besar siswa mampu menjawab soal instrumen test keterampilan berpikir kritis.

Hasil uji hipotesis menunjukan thitung $>t_{\text {abel }}$ yaitu thitung $6,509>t_{\text {tabel }} 2,020$ yang artinya terdapat pengaruh penerapan metode pembelajaran praktikum terhadap keterampilan berpikir kritis dengan persamaan 
regresi : $1.341 \mathrm{X}$. Koefisien bernilai positif artinya terdapat hubungan positif antara metode pembelajaran praktikum dengan keterampilan berpikir kritis siswa. Uji kebaikan model menunjukan Koefisien determinasi ( $R$ Square) sebesar $0,502 \%$ variabel berpikir kritis dijelaskan oleh variabel penggunaan metode pembelajaran praktikum dan sisanya sebesar $0,498 \%$ dijelaskan oleh variabel lain. Hal ini menunjukan bahwa penerapan metode pembelajaran praktikum cocok diterapkan di kelas VIII E SMP Negeri 3 Sumber.

Saran

Guru hendaknya menerapkan metode pembelajaran yang sesuai agar dapat memfasilitasi keterampilan berpikir kritis siswa.

Matematika bukan pelajaran penghafalan tetapi blajar matematika harus sering mengerjakan soal-soal latihan, saat ini siswa cenderung menghafal rumus tetapi masih bingung ketika mengaplikasikannya ke dalam soal, untuk itu pemberian latihan dan Pekerjaan Rumah dari guru dapat melatih kemampuan siswa ketika menjawab soal.

Kedisiplinan siswa dan keberanian siswa untuk bertanya ketika belajar juga penting agar proses belajar mengajar berjalan dengan baik.

Sekolah hendaknya memperbaiki fasilitas belajar mengajar agar siswa dan guru merasa nyaman ketika proses pembelajaran.

\section{DAFTAR PUSTAKA}

Anisah., 2011. Teori Belajar Orang Dewasa. Bandung: PT. Remaja Rosdakarya.
Aqib, Z., 2010. Profesionalisme Guru dalam Pembelajaran. Surabaya: Insan Cindekia.

Rofiah, Dkk., 2013. Penyusunan Instrumen Tes Kemampuan Berpikir Tingkat Tinggi Fisika pada Siswa SMP. Jurnal Pendidikan Fisika. Volume 01(No. 2), 17-22.

Susanti, Dkk., 2011. Studi Perbandingan Hasil Belajar Matematika Siswa dengan Menggunakan Model Pembelajaran Kooperatif Tipe The Learning Celll dan Tipe Artikulasi di Kelas VII SMPN 7 MA Jambi. Jurnal ISSN. Volume 01(No. 02), 49-59.

Fachrurazi., 2011. Penerapan Pembelajaran Berbasis Masalah untuk Meningkatkan Kemampuan Berpikir Kritis dan Komunikasi Matematis Siswa Sekolah Dasar. Jurnal ISSN, (No.1), 76-89.

Fahmy, F., 2013. Pengaruh Penggunaan Metode Pembelajaran Problem Solving Terhadap Kemampuan Berpikir Kreatif Siswa Kelas VIII MTs Itibahusysyubban Ujungsemi Kabupaten Cirebon. Skripsi. Cirebon. IAIN Syekh Nurjati

Hamdani., 2010. Strategi Belajar Mengajar. Bandung: CV. Pustaka Setia.

Haniah, N. S., 2013. Pengaruh Kompetensi Guru, Lingkungan Masyarakat dan Minat Belajar Terhadap Hasil Belajar Siswa pada Mata Pelajaran Kewirausahaan. Skripsi. Bandung. Universitas Pendidikan Indonesia

Hayat, M. S., \& Anggraeni, S., 2011. Sikap Ilmiah Siswa Practicum 
Based Learning On Invertebrate Concept To Students' Scientific Attitude Development. Jurnal Penelitian. Volume 02, 141152.

Hidayati, N., 2012. Penerapan Metode Praktikum dalam Pembelajaran Kimia untuk Meningkatkan Keterampilan Berpikir Tingkat Tinggi Siswa pada Materi Pokok Kesetimbangan Kimia Kelas XI SMK Diponegoro Banyuputih Batang. Skripsi. Semarang. IAIN Walisongo

Mahmuzah, R., \& Ikhsan, M., 2014.

Peningkatan Kemampuan

Berpikir Kritis dan Disposisi Matematis Siswa SMP dengan Menggunakan Pendekatan Problem Posing. Jurnal Didaktik Matematika. Volume 01(No. 2), 43-53.

Mappeasse, M. Y., 2010. Pengaruh Cara dan Motivasi Belajar Terhadap Hasil Belajar Programmable Logic Controller ( PLC) Siswa Kelas III Jurusan Listrik SMK Negeri 5 Makassar. Jurnal MEDTEK. Volume 01(No. 2), $1-6$.

Purwanto, N., 2000. Prinsip-Prinsip dan Teknik-Teknik Evaluasi Pengajaran. Bandung: PT. Remaja Rosdakarya.

Riduwan., 2003. Dasar-dasar Statistika. Bandung: Alfabeta. Rohati., 2011. Pengembangan Bahan Ajar Materi Bangun Ruang dengan Menggunakan Strategi Relating, Experiencing, Applying, Cooperating, Transferring (React) Di Sekolah Menengah
Pertama. Jurnal ISSN.

Volume 01(No. 02), 61-73.

Slameto., 1995. Belajar dan Faktorfaktor yang Mempengaruhinya. Jakarta: Rineka Cipta.

Sugiarti, R., 2001. Analisis Regresi dan Korelasi Sederhana. Artikel

Sukmandari., 2012. Pengaruh Motivasi Berprestasi dan Partisipasi Guru dalam MGMP Terhadap Kompetensi Profesional Guru Matematika. Jurnal Penelitian. Volume 01(No. 3), 313-330.

Sumiyati., 2008. Metode Pembelajaran. Bandung: Wacana Prima.

Suwarma, D. M., 2009. Suatu Alternatif Pembelajaran Berpikir Kritis Matematika. Jakarta: Cakrawala Maha Karya.

UU RI No. 20 Tahun 2003., 2013. Undang-undang tentang Pendidikan Nasional. PP-IKI

Wahjudi., 2003. Power dari Uji Kenormalan Data. ArtikelWangid, M. N. (2009). Sistem Among pada Masa Kini : Kajian Konsep dan Praktik Pendidikan. Jurnal Pendidikan. Volume 39, 129140.

Winataputra, E. S., 2001. Metode Penelitian Kuantitatif. Jakarta: Depdikbud.

Wulandari, D. A., 2013. Penerapan Desain Pembelajaran Kimia Berbasis Brain Based Learning untuk Meningkatkan Kemampuan Berpikir Kritis dan Hasil Belajar Siswa SMA N 1 Tengaran. Skripsi. Semarang. UNNES 